SPECIAL ARTICLE / ARTIGO ESPECIAL

\title{
Brazil in the face of new SARS-CoV-2 variants: emergencies and challenges in public health
}

\section{O Brasil perante as novas variantes de SARS-CoV-2: emergências e desafios em saúde pública}

\begin{abstract}
Flavia Maria Darcie Marquitti' (D), Renato Mendes Coutinho" (D), Leonardo Souto Ferreirall' (D), Marcelo Eduardo Borges ${ }^{\mathrm{IV}}$ (D), Tatiana Pineda Portellav (D), Rafael Lopes Paixão da Silva"l' (D), Otavio Canton"II (ID, Silas Poloni"l (D), Caroline Franco"II ID, Verônica Coelho ${ }^{\mathrm{VI}}$ (D), Lorena Barberia ${ }^{\mathrm{VII}}$ (D), Monica de Bolle ${ }^{\mathrm{VIII}}$ (D), Alexandra Crispim Boing ${ }^{1 \mathrm{X}}$ (ID), Maria Rita Donalisiox (D), Antonio Fernando Boing ${ }^{\mid x}$ (D), Antônio Augusto Moura da Silva ${ }^{\mathrm{Xl}}$ (D), Paulo Inácio Pradov ${ }^{\mathrm{D}}$, Maria Amélia de Sousa Mascena Veras ${ }^{\mathrm{XII}}$ (D), Roberto André Kraenkel"I (D)
\end{abstract}

\begin{abstract}
This article discusses the epidemic situation of Covid-19 in Brazil, in the face of the emergence of a new strain called P.1, which is more transmissible and may be associated with reinfection. Given the collapse of hospital care in Manaus in January 2021 and the results of three recent preprints, each that reports increased transmissibility of the P.1 variant, we propose some urgent measures. Genomic surveillance based on multi-step diagnostics, starting with RT-PCR type tests and up to sequencing, should be established. Efforts to identify reinfections associated with this variant and the update of its definition in protocols should be prioritized, and studies on the efficacy of currently available vaccines in Brazil concerning the new variant should be conducted. We also propose improving the Brazilian health surveillance system such that genomic surveillance is coordinated and thereby better able to respond to future emergencies in a more timely fashion. We call on the public agents involved in health surveillance to share data and information regarding the epidemic in a clear, fast and transparent way. Finally, we propose a greater engagement in inter-institutional cooperation of all those involved in the response and production of knowledge about the pandemic in our country.
\end{abstract}

Keywords: Coronavirus infections. Surveillance. Epidemics.

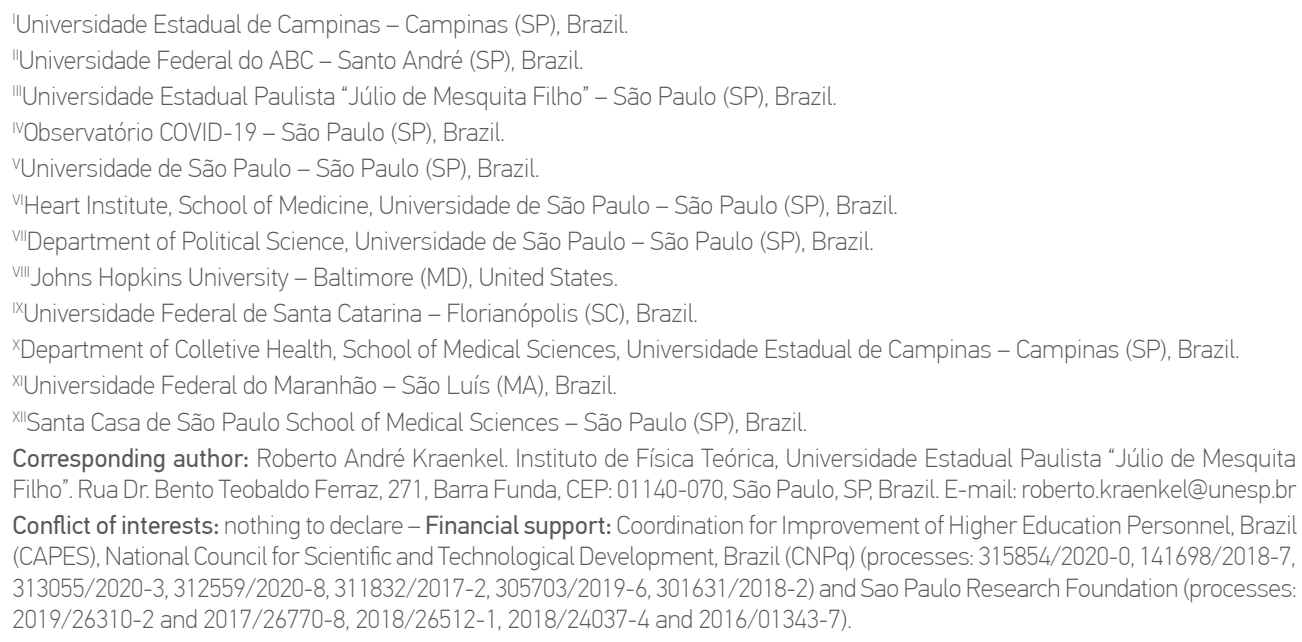
Filho". Rua Dr. Bento Teobaldo Ferraz, 271, Barra Funda, CEP: 01140-070, São Paulo, SP, Brazil. E-mail: roberto.kraenkel@unesp.br Conflict of interests: nothing to declare - Financial support: Coordination for Improvement of Higher Education Personnel, Brazil (CAPES), National Council for Scientific and Technological Development, Brazil (CNPq) (processes: 315854/2020-0, 141698/2018-7, 313055/2020-3, 312559/2020-8, 31 1832/2017-2, 305703/2019-6, 301631/2018-2) and Sao Paulo Research Foundation (processes: 2019/26310-2 and 2017/26770-8, 2018/26512-1, 2018/24037-4 and 2016/01343-7). 
RESUMO: Este artigo discute a situação epidêmica da COVID-19 no Brasil diante do aparecimento de uma nova linhagem, chamada P.1, mais transmissível e com possível reinfecção associada. Tendo em vista o colapso do atendimento hospitalar em Manaus em janeiro de 2021 e os resultados de três preprints recentes, dos quais todos encontraram maior transmissibilidade da variante P.1, propomos algumas ações urgentes: o estabelecimento de uma vigilância genômica baseada em diagnóstico em múltiplos passos, iniciando com os testes do tipo transcrição reversa seguida de reação em cadeia da polimerase (RT-PCR) até o sequenciamento; um esforço imediato na identificação de reinfecções associadas à nova variante, com a atualização dos protocolos de definição; e estudos sobre a eficácia das vacinas disponíveis no Brasil na vigência da nova variante. Propomos, ademais, o aprimoramento do sistema de vigilância em saúde brasileiro para que seja articulado com a vigilância genômica, de forma a responder mais oportunamente a emergências futuras. Chamamos os agentes públicos implicados na vigilância em saúde para que compartilhem dados e informações referentes à epidemia de forma clara, rápida e transparente. Finalmente propomos maior engajamento na cooperação interinstitucional de todos os envolvidos na resposta e produção de conhecimento sobre a pandemia em nosso país.

Palavras-chave: Infecções por coronavírus. Vigilância. Epidemias.

On the basis of data from Manaus, three recent preprints concluded that the P.1 variant of SARS-CoV-2 is much more transmissible than the variants that previously prevailed in the city. Despite the use of different methods and techniques, there is a convergence of the three studies on the greater transmissibility of the variant.

Naveca et al. ${ }^{1}$, using phylogenetic methods and under the assumption that reinfections are rare, suggested that the P.1 variant is at least twice as transmissible as the parental strain when estimating the effective reproduction number $(\mathrm{Re})$ to be 2.2 . Faria et al. ${ }^{2}$ integrated mortality data and genomic data and, using a Bayesian model of epidemic dynamics, estimated the P.1 transmissibility rate to be on the order of 1.4 to 2.2 times more than the parental line and with $25-61 \%$ evasion of immunity. Coutinho et al. ${ }^{3}$ analyzed the number of hospitalizations over time since the variant appeared in November 2020 and the concomitant increase in the frequency of the variant in sequenced samples. With a mathematical model of the susceptible, exposed, infected, recovered type (SEIR), they adjusted parameters of transmissibility and probability of reinfection. This third study found transmissibility to be 2.6 (95\% confidence interval $(95 \% \mathrm{CI}) 2.4-2.8)$ times greater than that of the "wild" variant strain, and reinfections represented $28 \%$ of cases since the introduction of the variant. The three different methodologies not only concluded that the transmissibility of the P.1 variant is indeed high but reached similar conclusions as to its magnitude.

It is likely that variants of concern (VOCs) are already widespread across the country. On March 4, 2021, Fiocruz released a technical note presenting data on the distribution of VOCs in several states, showing that the percentage of COVID-19 cases caused by VOCs was very high, reaching more than $70 \%$ in some states ${ }^{4}$. Among the eight states 
investigated, only two (Minas Gerais and Alagoas) had a prevalence of variants with mutations of concern below $50 \%$. It is important to note that the test used by Fiocruz did not discriminate between the different VOCs. Moreover, at the time of writing this letter, there were no details about the sample design that gave rise to these results, nor about their statistical significance or the number of samples analyzed. Information is surely available, given the prevalence figures reported in percentages. Information gaps need to be quickly addressed to support decision-making and the implementation of COVID-19 coping measures.

Since the variant P.1 and the B.1.1.7 seem to circulate widely in the country, we present here what we believe to be important considerations.

As the studies cited above suggest that the P.1 variant is spreading rapidly in many Brazilian states, a surveillance system to detect it and help respond in a timely manner should be implemented, ideally integrating epidemiological and genomic surveillance. Brazil has many laboratories throughout the country capable of carrying out, or actually carrying out, the sequencing of SARS-CoV-2, especially the Fiocruz Network, the Virus Network of the Ministry of Science, Technology and Innovations (MCTI) and the network integrated by the central public health laboratories (LACEN). Other smaller networks are formed by academic institutions, in addition to private laboratories. Despite this, until now, sequencing results and their analysis have not been made available in a timely manner, making their usefulness difficult in the event of an emergency. A more immediate response to complement these efforts would be to establish common routines and criteria, which would include multi-step diagnostics based on: use of common RT-PCR tests, PCR tests capable of identifying a suspected VOC, and finally, sequencing. This would help accelerate genomic investigation and the rapid tracking of the spread of VOCs. For the strategy to be effective in this urgent surveillance effort, synergistic action and a joint effort must be made to coordinate public and private laboratories, as well as municipal and state health departments.

Studies that investigate the ability of the P.1 variant to escape previously acquired immunity are imperative. Although there are confirmed cases of P.1 reinfection, there are no conclusive results on how often they are presently. Even more urgent is the improvement of surveillance of reinfections. In the protocol currently used, suspected cases of reinfection are considered to be people diagnosed with respiratory infections by SARS-CoV-2 with an interval of at least 90 days between the two events, both confirmed by RT-PCR tests, or sequencing of the viral genome, to prove that they are two different variants in the first and second infections ${ }^{5}$. However, only suspected cases are investigated for which there are biological samples from the two infection events ${ }^{5}$. The lack of available samples and laboratory support, especially from LACEN, represents obstacles in confirming two different episodes of infection with different viral variants. In addition, there are records of reinfections at intervals far less than 90 days. Thus, what we already know points to the need to redefine cases and protocols, as well as improvements in infrastructure, so that we also have a timelier and more sensitive surveillance of reinfections. 
The effectiveness of current vaccines with respect to the P.1 variant needs to be studied and responded to urgently. With the exception of preliminary in vitro evidence of decreased titers of neutralizing antibodies with the use of CoronaVac ${ }^{6}$ and reports in the press about the presumed maintenance of these antibodies for the AstraZeneca/Oxford vaccine, very little is known about the protection afforded by vaccines against as VOCs. A recent preprint found cross-reactivity of neutralizing antibodies to P.1, induced by natural infection by the South African variant, B.1.351'. These data suggest that the updated VOC vaccines that emerged in South Africa may be effective against P.1, but further studies are needed to establish whether this could be a promising path for vaccine updates. In addition, the acceleration of vaccination is urgent, with expansion of vaccine availability for populations at higher risk, as well as for other groups in Brazil.

Since mid-February, there has been a general increase in the number of cases of COVID19 and associated deaths in most Brazilian states. Given this public health emergency, actions must be taken immediately to prevent the spread of the virus, while short- and medium-term surveillance efforts are strengthened. Without these strategies, the risk of collapse of the hospital infrastructure significantly increases, as observed in Manaus in January and as already observed in other states and municipalities at the time of writing this letter. Clearly, in the last half of February 2021, the increase in cases in several regions of the country led to an overload of the hospital system in most of the most populous Brazilian cities. In them, occupancy rates of general hospital and intensive care unit (ICU) beds were close to or even above their maximum limit, both in public and private institutions, with a substantial contingent of people who were left without access to ICU beds when there was a clinical need for their use.

Non-pharmacological interventions must be implemented or reinforced immediately in the affected states and municipalities. Such measures include strict social distancing policies that significantly restrict the movement of people during the day and night for a minimum period of 21 days, or until significant reductions in the transmission of the virus and emergence of new cases and hospitalizations are seen.

A highly transmissible variant accelerates the pace of the epidemic in Brazil and poses a threat to neighboring countries, and the rest of the world. In fact, the threat posed by P.1 and other VOCs that may arise in Brazil as a result of the uncontrolled epidemic has already been reiterated by the international press. So far, P. 1 has been found in 26 countries and its community transmission has been confirmed in Belgium, Italy, Colombia and Brazil. The Brazilian federal government and several local governments have repeatedly refused to adopt containment efforts based on scientific data, notably stricter restrictions on the functioning of non-essential services, effective testing actions followed by isolating people with active infections and tracking their contacts, policies to restrict international and domestic travel and other non-pharmacological measures necessary to contain the spread of P.1. In the absence of these measures, which should be led by the federal government, intra- and interstate coordination is more essential than ever. 
Finally, it is imperative to improve our health surveillance system, including virologi$\mathrm{cal} /$ genomic surveillance. If the results are confirmed that several states have high VOC circulation, this will be the same as saying that we were unable to detect the arrival of these variants in a timely manner, and that we are only able to detect them when they represent the majority of cases. We know that the inability of our surveillance system to respond promptly in this episode has structural causes, such as underfunding Brazilian public health and science. In this context, we call on public officials to share data and information regarding the epidemic in a clear, fast and transparent way. It is also essential to engage the institutions in coordinated actions that integrate LACEN, the Fiocruz Network, research groups and the private network. The Brazilian scientific community, managers and public health workers need to address these issues if Brazil is to improve its capacity to respond to the pandemic, the SARS-CoV-2 variants and other public health emergencies in the future.

\section{REFERENCES}

1. Naveca F, Nascimento V, Souza V, Corado A, Nascimento F, Silva G, et al. COVID-19 epidemic in the Brazilian state of Amazonas was driven by longterm persistence of endemic SARS-CoV-2 lineages and the recent emergence of the new Variant of Concern P.1. 2021. https: / / doi.org/10.21203/rs.3.rs-275494/v1

2. Faria NR, Mellan TA, Whittaker C, Claro IM, Candido DS, Mishra S, et al. Genomics and epidemiology of a novel SARS-CoV-2 lineage in Manaus, Brazil. medRxiv 2021. https: / / doi.org/10.1101/2021.02.26.21252554

3. Coutinho RM, Marquitti FMD, Ferreira LS, Borges ME, Silva RP, Canton O, et al. Model-based evaluation of transmissibility and reinfection for SARS-CoV-2 P.1 variant. medRxiv 2021. https: / / doi. org/10.1101/2021.03.03.21252706

4. Fundação Oswaldo Cruz. Fiocruz detecta mutação associada a variantes de preocupação do Sars-Cov-2 em diversos estados do país [Internet]. Rio de Janeiro: Fiocruz; 2021 [acessado em 12 mar. 2021]. Disponível em: https://portal.fiocruz.br/sites/portal.fiocruz. br/files/documentos/comunicado_variantes_de_ preocupacao_fiocruz_2_2021-03-04.pdf. Acesso em: 12 mar. 2021.
5. Brasil. Ministério da Saúde. Nota Técnica n ${ }^{\circ} 52 / 2020$ CGPNI/DEIDT/SVS/MS [Internet]. Brasil: Ministério da Saúde; 2020 [acessado em 8 mar. 2021]. Disponível em: https://www.gov.br/saude/pt-br/media / pdf/2020/dezembro/10/11-sei_nota-reinfeccao.pdf

6. Souza WM, Amorim MR, Sesti-Costa R, Coimbra LD, Toledo-Teixeira DA, Parise PL, et al. Levels of SARSCoV-2 Lineage P.1 Neutralization by Antibodies Elicited after Natural Infection and Vaccination. Lancet 2021. https: / / doi.org/10.2139/ssrn.3793486

7. Moyo-Gwete T, Madzivhandila M, Makhado Z, Ayres F, Mhlanga D, Oosthuysen B, et al. SARSCoV-2 501Y.V2 (B.1.351) elicits cross-reactive neutralizing antibodies. BioRxiv 2021. https:// doi. org/10.1101/2021.03.06.434193

\section{Received on: $03 / 17 / 2021$ \\ Accepted on: 03/23/2021 Preprint on: 03/23/2021 https://doi.org/10.1590/SciELOPreprints.2001} Authors' contributions: All authors contributed equally to this article. 